\title{
Does market concentration affect prices in the urban water industry?
}

Germà $\mathrm{BEL}^{+}$

Francisco GONZÁLEZ-GÓMEZ ${ }^{++}$

Andrés J PICAZO-TADEO*

+ Universitat de Barcelona \& Barcelona Graduate School of Economics, Spain

(gbel@ub.edu)

${ }^{++}$Universidad de Granada, Spain (fcojose@ugr.es)

* Corresponding author. Universidad de Valencia. Dpto Economía Aplicada II. Campus de Tarongers, 46022 Valencia, Spain; phone+34963828349 (andres.j.picazo@uv.es)

\begin{abstract}
This paper analyzes the relationship between market concentration in the private segment of the water industry and water prices with a sample of municipalities located in the Southern Spanish region of Andalusia. In doing so, several Heckman sample selection models are estimated with the main finding being that market concentration increases the price of water for residential use charged by private companies. The main policy recommendation is that urban water service privatization must be accompanied by the appropriate regulatory and institutional frameworks to promote competition among businesses and monitor water pricing.
\end{abstract}

Keywords: market concentration; privatization; water industry; water price; Spain.

\section{EnVironment and Planning C: Government and Policy, in press}

\section{Introduction}

Many governments have implemented measures of economic liberalization since the late 1970s. Inspired by the Public Choice Theory, decisions were taken to reduce the presence of the public sector in the economy in favor of private enterprises. Following these regulatory changes, many local governments opted to outsource and in some cases, privatize some municipal services (Bel and Fageda, 2009). 
Among the services that are a competence of local governments, the urban water supply has generated the most controversy regarding privatization; in fact, reform in many developed economies has not addressed the privatization of urban water services. In most OECD countries, less than $10 \%$ of the population and in some cases none whatsoever are supplied by the private water industry. Only in France, England and the Czech Republic does privatization represent more than 50\%. In Greece, Italy and Spain, privatization accounts for between $30 \%$ and 50\%, while in Australia, Germany, Hungary, Mexico, Portugal, Slovakia and the United States, the figure ranges from $10 \%$ to $30 \%$ (Pérard, 2009). It is worth noting that privatization in Europe predominantly takes the form of concessions to private firms (or contractual public-private partnerships); the United Kingdom and the Czech Republic, where privatization has been mostly carried out through the sale of assets, are however significant exceptions.

Governments are reluctant to privatize the urban water service due to the nature of the water industry. One peculiarity is that this service provides access to a basic good (GarcíaValiñas et al, 2010). Moreover, it is difficult to introduce competition into the water market and the contracting process of water services is more prone to suffering competition failures than other public services (Bel et al, 2010). A third feature is the high transaction costs associated to the privatization of the water service (Bel and Warner, 2008).

One argument that has also been traditionally used to oppose the privatization of the urban water service is that private enterprises charge higher prices, without necessarily improving the quality of the service. Evidence shows that water prices are higher in private firms than public firms in France (Carpentier et al, 2006; Chong et al, 2006a), Germany (Ruester and 
Zschille, 2010), and large cities in Spain (Martínez-Espiñeira et al, 2009). ${ }^{1}$ One possible explanation for the higher prices charged by private enterprises has to do with market structure, i.e. imperfect competition among the few companies operating at national level; furthermore, public delivery is associated to higher subsidies from the public budget.

Several reasons might explain why markets differ in their degree of competition (Belleflamme and Peitz, 2010). Whatever the reason, uncompetitive markets tend to result in a higher degree of market power for firms, which can be defined as the ability to raise prices above the perfectly competitive level. Belleflamme and Peitz (2010) define two ways of measuring market power. Firstly, through the difference between prices and marginal costs. However, as in the empirical case in this study, marginal costs are often not directly observable and even prices are obscure. The second way to measure the market power of firms is by means of indexes that reflect the level of concentration in the market.

In this context, the objective of our research is to analyze the relationship between market structure in the water industry and water prices of private companies. ${ }^{2}$ To the best of our knowledge, only two studies have addressed this issue previously, both focusing on the French case. Neither of them obtains robust evidence on the relationship between competition and water prices. On the one hand, Garcia et al (2005) shows that the presence of a small local firm (outsider) in a competitive bidding process does not automatically increase

\footnotetext{
${ }^{1}$ Notwithstanding, a recent paper by García-Valiñas et al (2012) has studied the price of water for residential use in both small and large cities in Southern Spain, concluding that private companies charge lower prices than public ones.

${ }^{2}$ Furthermore, let us emphasize that we do not intend to analyze all complexities of every management option for the urban water cycle, as it would go far beyond our aim and perhaps would deserve a full paper on its own. For varieties of management options in Spain, the environment of our case study, see Warner and Bel (2008) and Bel et al (2013); also, see Bakker (2010) and Furlong and Bakker (2010) for a wider and more global analysis.
} 
competition leading to a fall in prices. On the other hand, Chong et al (2006b) finds that when operators control the monopoly for the entire duration of the contract, their prices are not mitigated by a direct competition effect. Furthermore, no relationship is found between the prices charged by private operators and ex post competition in water contracting.

In the two aforementioned papers, organizational choices are considered randomly chosen. However, this assumption constitutes a serious limitation because organizational choices might be influenced by numerous characteristics of operating environments, some of which could also affect water prices. Chong et al (2006b) acknowledged this limitation and suggested that future research overcome it by making organizational choice endogenous. This is the approach we take in our analysis by simultaneously estimating both a price equation and a privatization equation with Heckman sample selection models. In doing so, we use data related to the moment in time when privatization was decided, thus obtaining more robust results.

Our paper performs an analysis of the relationship between market concentration and water pricing in the private segment of the water industry based on data from a sample of municipalities located in the Southern Spanish region of Andalusia. We use variables representing both the degree of concentration in the industry at the time the service is privatized and the market share of the company that manages the service once it has been awarded. Contrary to the results obtained in previous research, we find evidence supporting the fact that market concentration influences the pricing of water for residential uses. The implication of this result for policymakers is straightforward: market concentration makes it advisable to create (or strengthen) a regulatory and institutional framework to monitor pricing.

The article is organized as follows. After this Introduction, Section 2 describes the regulatory framework for privatizing water services in Spain and the market structure in Andalusia. 
Section 3 explains the methodology, describes the data and establishes the main hypothesis to be verified. Section 4 comments on the results and their policy implications. A final Section concludes.

\section{Privatization of urban water management in Andalusia}

\subsection{Legal framework}

The legal framework that regulates the management of municipal services in Spain is made up of Law 7/1985 (Local Government Regulations) and Law 57/2003 (Measures for the Modernization of Local Government). ${ }^{3}$ Article 25 of the first of these laws stipulates that local governments are responsible for the urban water supply, although they are empowered to decide the legal form of such provision. Current legislation establishes different possibilities. In the first place, the local government may choose to manage the service from the council itself (in-house) or to outsource it. In the second case, management may be either transferred to a public company or privatized through either a private firm (contractual public-private partnership, or full privatization) or a mixed firm (institutional public-private partnership, or partial privatization).

Although in Spain there has traditionally been a preference for public management, different forms of public-private partnerships have gained significance in recent decades, including lease contracts, mixed-owned companies, concessions and management contracts (Olmos-Giupponi, 2013). Among them, concession agreements are the most widespread form of privatizing local water services. They are made official through a management contract of public services by which the local government, which usually retains the ownership of

\footnotetext{
${ }^{3}$ It is worth noting that by means of the Law 27/2013 of Rationalization and Sustainability of Local Administration, passed on December 30th 2013, the function of coordination of urban water delivery in municipalities below 20,000 inhabitants has been transferred to provincial governments.
} 
the service, entrusts operations to a natural person or legal entity. Through a concession, the private company will manage the service at its own risk and venture during the term of the contract. Mixed-ownership is also acquiring increasing relevance in the management of water service, and can be considered as a partial privatization that allows the promotion of public interests to be combined with the benefits of private management (Bel and Fageda, 2010). Ownership is shared between the public partner, who usually maintains ownership of $51 \%$ of the capital and is supposed to ensure the public interest, and the private partner, who has know-how of the industry and is often in charge of the day-to-day management (Bel and Warner, 2008, González-Gómez et al., 2009).

The full or partial transfer of water service management to a private company is awarded for a certain period of time after a competitive bidding process. There is a limit of fifty years in contracts that involve the construction of infrastructure and operations, and twentyfive years in those which only involve running the service. Candidates in the bidding process place a first-price sealed-bid in response to a notice announcing the public tender of the contract of water service management. This announcement includes the technical and economic conditions of the contract and the procedure and assessment criteria, also detailing the commitments that the contractor will have to fulfill after signing the contract. Bidders must submit their technical and financial proposal in sealed envelopes and the contract is awarded to the company that makes the most advantageous proposal considering a number of criteria.

\subsection{Privatizing water services in Andalusia}

Andalusia is a European region located in Southern Spain with a surface area of $87,268 \mathrm{~km}^{2}$ and a population of around 8.4 million inhabitants. Administratively, this region is made up of 8 provinces and 771 municipalities. In 2009, less than $24 \%$ of these municipalities had 
fully or partially privatized the management of urban water services; in 53\% of them, management had been completely transferred to a private company, while just $47 \%$ had delegated management to a public-private company. While municipalities mainly opted for full privatization in the late $80 \mathrm{~s}$ and the first half of the $90 \mathrm{~s}$, mixed firms have been preferred since the end of the 90s (Ruiz-Villaverde et al, 2010). Nonetheless, as also noticed by Olmos-Guiupponi (2013) for the Spanish case, recent trends in Andalusia show a certain slowing down in privatizations. ${ }^{4}$

One of the main features of the water market in Andalusia is the high concentration in a few companies, as shown in Table 1 by the scores recorded by CR1 and CR2, which measure the market share of the leading firm in the area and that of the two leading firms taken together, respectively. Together, the two largest firms (Aquagest and Aqualia) supply water to $57 \%$ of the municipalities that have fully or partially privatized management and to nearly $80 \%$ of the population. ${ }^{5}$ Aquagest belongs to Aguas de Barcelona (Agbar), the holding that comprises over 150 companies and around 13,000 employees and provides water services not only in Spain but also in countries like the United Kingdom, Mexico, China,

\footnotetext{
${ }^{4}$ While some new announcements of privatization have simply been stopped because of the strong opposition of citizens, in others cases existing contracts have been cancelled due to breaches by private companies; finally, there are also cases in which once the contract has expired, the local government has decided to return provision of water services to public management (RuizVillaverde et al, 2010).

${ }^{5}$ The greater concentration in terms of population is probably due to the fact that once companies gain a certain level of market power they show more interest in new privatization tenders for the most populated cities. However, it is worth mentioning that some highly populated Andalusian municipalities such as Seville and Córdoba maintain the public provision of water services. The local governments of these two important cities, traditionally from left-ring parties, have advocated the public management of local services as an essential principle of their ideological postulates, e.g., the public company that provides water services in Seville aims to apply the principles of fairness and equity in determining water prices (Castillo-Manzano et al, 2013).
} 
Chile, Cuba, Colombia and Algeria. Aqualia is part of Fomento de Construcciones y Contratas $(F C C)$, a holding company that, in addition to providing water services to more than 850 Spanish municipalities, is also present in 54 countries, including China, Mexico, Portugal, the Czech Republic, Poland and Algeria.

The Herfindahl-Hirschman Index (HHI) ${ }^{6}$ also indicates a high degree of concentration. According to the Federal Trade Commission and the US Department of Justice (USDJ\&FTC, 2010), markets can be categorized as unconcentrated (HHI below 0.10), moderately concentrated (HHI between 0.10 and 0.18 ) and highly concentrated (HHI above 0.18). Furthermore, the European Commission (EC, 2004) establishes that competition may be considered tough enough in markets with a HHI below 0.20. Taking these figures as benchmarks, the market in the private sector of the Andalusian water industry can be considered as highly concentrated, as it is also the case in the rest of Spain (González-Gómez et al, 2012).

\section{Methodology, data and hypotheses}

\subsection{Methodological notes}

Assessing the effect of market concentration on the price of water charged by private companies is not straightforward. There are several reasons for this. In the first place, privatization does not occur randomly. Numerous features of operating environments are likely either to make the management of the urban water service more attractive for private firms or to influence the willingness of local governments to privatize. Secondly, private prices are only observed if the municipality has previously privatized the urban water service. Fur-

\footnotetext{
${ }^{6}$ This index is calculated by squaring the market share of each firm competing in the market and then summing the resulting numbers. It approaches zero when a market consists of a large number of firms of relatively equal size and increases both as the number of firms in the market decreases and as their disparity in size increases.
} 
thermore, some variables may remain hidden to the researcher, while simultaneously affecting both the likelihood of privatization and the price of water once the service has been privatized. Under these circumstances, conventional ordinary least square regression methods yield biased results due to the existence of sample selection bias (Wooldridge, 2002). In order to overcome this difficulty, we use Heckman selection models (Heckman, 1976, 1979).

The Heckman selection model estimates two equations simultaneously, namely, the outcome equation and the selection equation. In our case, the outcome equation models the price established by private firms for water for residential uses as a function of a series of explanatory variables, namely $\mathrm{X}_{\text {Price, }}$ including those representing market concentration:

Water price $=\beta X_{\text {Price }}+\varepsilon_{\text {Price }}$

where $\beta$ is a vector of parameters to be estimated and $\varepsilon_{\text {Price }} \sim N(0, \sigma)$.

However, the dependent variable in the outcome equation, i.e., private prices for water, is only observed for municipalities where the urban water service has been previously privatized. The privatization process is modeled assuming that there is a latent regression relationship or selection equation in which the privatization choice depends on a series of variables $Z_{\text {Privatization: }}$

Privatization $=\delta Z_{\text {Privatization }}+\varepsilon_{\text {Privatization }}$

$\delta$ being a second vector of unknown parameters and $\varepsilon_{\text {Privatization }} \sim \mathrm{N}(0,1)$.

Furthermore, it is assumed that the error terms in the price equation and the privatization equations are jointly normally distributed with a correlation rho. The estimation of the Heckman two-equation model controls for the part of the privatization decision that is correlated with the error term in the price equation and requires the existence of at least one 
variable that affects privatization, but not the price of water. If the correlation between the error terms in the selection and outcome equations is statistically significant, the Heckman selection model yields consistent and asymptotically efficient estimates for all the parameters in both equations.

\subsection{Data and hypotheses}

We use information from 715 Andalusian municipalities, which represent $93 \%$ of the municipalities in the region. ${ }^{7}$ In 2009,553 of these municipalities provided urban water services publicly, either in-house or by contracting out to a public firm, while management had been privatized in 162 municipalities, either totally (77 municipalities) or partially (85 municipalities). The sample is representative of almost $90 \%$ of the municipalities that had privatized the management of water services in year 2009 .

\subsubsection{The price equation}

The price of water in Andalusia is different in each municipality, except in those cases where the same company provides water services to several neighboring towns and chooses to set the same price for the entire service area. In this regard, it is worth mentioning that in Andalusia the regulatory and institutional framework does not provide strict guidelines on what the structure of the pricing system or the level of water prices for residential use should be.

In all the municipalities within the sample, urban water suppliers charge non-linear and non-uniform prices, with tariffs divided in two parts: a fixed quota for the service connection and a variable quota that rises in accordance with blocks of consumption. The lack of

\footnotetext{
${ }^{7}$ Some municipalities are not included in the sample due to a lack of information for one or more of the variables involved in our analysis.
} 
homogeneity among municipalities in water tariffs and the unavailability of information about the distribution of consumption make it difficult to build a variable to represent the price of water for residential uses. In order to overcome this difficulty, we have used the tariff structure in each municipality to calculate, as in Chong et al (2006a), the price of a representative bill corresponding to the consumption of $15 \mathrm{~m}^{3}$, which is the average consumption observed in Andalusia (INE, 2011). This price includes both the fixed quota and the price for the water consumed and is used as the dependent variable in our price equation. Furthermore, in order to test the robustness of our estimations, the price of two more bills corresponding to average consumptions of 10 and $20 \mathrm{~m}^{3}$, respectively, have also been calculated. Table 2 provides some descriptive statistics for water prices in our sample showing the great differences that exist across municipalities.

In order to explain price differences we have considered the variables described in Appendix 1. Some descriptive statistics can be found in Table 3. The choice of these variables is based on the previous literature (Garcia et al, 2005; Carpentier et al, 2006; Chong et al, 2006a, 2006b; González-Gómez and Guardiola, 2009; Martínez-Espiñeira et al, 2009; Thorsten et al, 2009; Ruester and Zschille, 2010; González-Gómez et al, 2011) and is conditioned by the availability of statistical information.

As is usual in this type of analysis, we have considered a series of variables accounting for the socioeconomic characteristics of the environment and the technical characteristics of the water service. In all instances, they have an impact on service costs and, therefore, on water prices. Concerning socioeconomic features, we have introduced the variables POPULATION and DENSITY OF POPULATION, their effect on prices being ambiguous (Martínez-Espiñeira et al, 2009). On the one hand, the larger a municipality, the more a supplier can exploit the economies of scale in the industry (Bottasso and Conti, 2009); however, this at the same time implies greater complexity in the management of the service, which can raise costs. 
On the other hand, higher population concentration leads to higher congestion expenses, while greater dispersion leads to higher pumping costs because of diseconomies of density (Kim and Clark, 1988). Regarding the technical characteristics of the service, we include the STRONG WATER TREATMENT variable, which is a dummy that identifies municipalities where it is necessary to carry out major water treatment in order to make it suitable for human consumption. As more complex treatment processes entail higher costs for the company, this variable is expected to be positively related to prices. $^{8}$

In Spain, it is common for a single company to provide urban water services to several adjacent municipalities. The strategy of expanding the service area allows companies to exploit the economies of scale and density in the industry and, consequently, to reduce average costs (González-Gómez and García-Rubio, 2008). In order to contrast the influence of this strategy on water prices, the dummy variable CONSORTIUM has been included, which is expected to be negatively related to water prices.

Furthermore, the dummy variable PRIVATE MANAGEMENT seeks to test whether there are differences between the prices charged by private companies or contractual public-private partnerships and mixed firms or institutional public-private partnerships. The control exerted over mixed companies by the public partnership can influence prices in two ways. On the one hand, it can contain prices better, while on the other hand, it can force companies to make decisions aimed at promoting general interests that imply higher costs and, therefore, higher prices. The expected effect of this variable is therefore uncertain. ${ }^{9}$ Finally, five

\footnotetext{
${ }^{8}$ In relation to the technical characteristics of the service, we also considered including the length of the delivery network as an explanatory variable, which could be positively correlated to the price of water. However, the high correlation between this variable and POPULATION has led us to exclude it from the estimation.

${ }^{9}$ Cruz and Marques (2012) have recently argued that, in spite of the theoretical advantages of institutional public-private partnerships, the empirical evidence for the case of the Portuguese water
} 
dummy variables representing the companies with the largest market share in Andalusia have also been included to control for differences in water pricing strategies among firms.

\subsubsection{Variables representing market structure}

In addition to the variables mentioned above, a set of variables aimed at measuring the market concentration in the Andalusian water industry has been considered. In Spain, given the legislation governing the privatization of water, the potential relationship between market structure and prices can be held in two different points in time, namely, when the concession is awarded and during the term of the contract when the supplier acts as a local monopoly.

Concerning the first of these times, a requirement for the bidders in an auction is to set a water price to be paid by service users. In order to capture this first relationship between market concentration and water prices, three alternative indicators of MARKET CONCENTRATION have been computed at provincial level, which is considered the relevant market regarding the availability of private vendors ${ }^{10}$, namely, $C R 1, C R 2$ and $H H I$, as defined in Section 2.2. In all cases, market shares are computed according to the population served. These variables were computed taking into account the value of each indicator in the year in which the local government decided to privatize the urban water service and aim to capture the competition risk perceived by the bidders in the competitive bidding process. A greater degree of concentration implies fewer potential competitors.

service shows that the complexity involved in their management usually leads to poor protection of the public interest.

${ }^{10}$ Spatial proximity has generally been accepted as an intensifier of price competition, although it has also been pointed out that in some local oligopolistic markets it might act as an inhibitor of price competition (Kuenne, 1989). 
The second time when the relationship between market structure and prices might exist is, as noted, when the contractor acts as a local monopoly. Spanish legislation allows water rates to be modified, which usually occurs annually. The process begins with the preparation of a tariff review record by the supplier company, which must then be approved by the municipal government. Important information asymmetries exist in water services and transaction costs are high (Brown and Potoski, 2005), so the company may impose its dominant position on the pricing proposal year in year out. The relationship between supplier market power and price is captured by the variable MARKET SHARE OF THE SUPPLYING FIRM, measured on the basis of the population supplied in the provincial market. The more market power a company has, the higher prices are expected to be. The reason is that the smaller the number of external references for local governments, the more asymmetric their information will be and the more benefits the supplying company will reap from its dominant position.

Concerning the annual review of tariffs, one might also expect water prices to increase as years go by. Indeed, the course of time since privatization can increase the market power of settled firms, thus eroding competition (Bel and Costas 2006; Dijkgraaf and Gradus, 2008), which might have made it easier to increase effective prices through the various tariff reviews. Thus, the variable YEARS SINCE PRIVATIZATION, which measures the number of years elapsed from the year of privatization to 2009 , is expected to be positively related to the price of water. ${ }^{11}$ However, one might expect this effect, while positive, to decrease over time, such that with the passing of time firms will tend to contain the rise in water prices. The reason is that contracts are limited in time, so the company will have to adjust its pric-

\footnotetext{
${ }^{11}$ There is a possibility that the municipalities that privatized earlier have the most limited opportunities for cost-containment. In this regard, it is worth noting that we do not consider the year in which the service was first privatized, but the year in which the last (that might not be the first) contract was awarded.
} 
ing strategy to take into account that the local government may reconsider its decision to privatize in the future. Therefore, as the end of the contract approaches, companies would adopt a pricing strategy that increases their options to renew the contract. Consequently, the coefficient of the variable YEARS SINCE PRIVATIZATION-SQUARED is expected to be negative and significant.

\subsubsection{The privatization equation}

In the equation of privatization, the dependent variable is a dichotomous variable that takes a value of zero if in 2009 the urban water service is provided publicly, either in-house or through a public firm, and one if the service has been either totally or partially privatized. The explanatory variables are those usually employed in this type of study, including $P O P U$ LATION, FINANCIAL BURDEN, INCOME PER CAPITA, PUBLIC EMPLOYMENT, NEIGHBORING EFFECT, CONSORTIUM, WATER CAPTURE SYSTEM, IDEOLOGY and MEDITERRANEAN RIVER BASIN. The definitions and sources of these variables are provided in Appendix 1. In addition, following the recommendation by Bel and Fageda (2007), the explanatory variables are measured at the time the decision to privatize the water service was taken, rather than at a later date, as is the case in most previous studies. As noted by Picazo-Tadeo et al (2012), by considering the time dimension of the variables we expect to enhance the explanatory power of our model.

\section{Results and policy implications}

The results of the estimation by maximum likelihood of our sample selection model in equations (1) and (2) are in Table 4. In order to test the robustness of the effect of market concentration on water prices, four different models have been estimated. In all models, socioeconomic and technical variables, as well as firm dummies, are included in the price equation as explanatory factors. In addition, models 1 to 3 include variables representing 
market concentration at the time when the decision to award the contract for the provision of the water service is taken ( $C R 1, C R 2$ and $H H I$, respectively), while model 4 includes the relevant variable once the contract has been awarded, namely, MARKET SHARE OF THE SUPPLYING FIRM. Furthermore, all models include the variable YEARS SINCE PRIVATIZATION and its square.

In all models, the value estimated for the parameter rho is statistically different from zero and stands at around 0.75 (p-values for the likelihood ratio test of the null hypothesis of independent equations are always below 0.001). This result indicates that the error terms in the price and privatization equations are positively correlated and justifies the use of a selection model to obtain consistent and asymptotically efficient estimates for the parameters of interest in the price and privatization equations.

Concerning these parameters let us start by briefly commenting on the results for the privatization equation. In line with previous research, the likelihood of privatization increases with the size of the municipality (variable POPULATION), indicating that in more complex environments local governments tend to delegate the management of water services searching for the know-how of private firms. Similarly, private companies may prefer to manage services in more populated cities, where investment per inhabitant is lower and expected profits are higher (Martínez-Espiñeira et al, 2009). ${ }^{12}$ However, the negative and statistically significant sign of the variable POPULATION-SQUARED indicates that this effect is decreasing. The probability of privatization also increases with INCOME PER CAPITA, the relationship being statistically significant; this confirms the hypothesis that private firms have more incentives to provide the water service in municipalities with higher income per inhabitant because profits are expected to be higher. The variable PUBLIC EMPLOYMENT is negatively

\footnotetext{
${ }^{12}$ Furlong and Bakker (2010) indicate, nonetheless, that direct delivery may not be optimal in small municipalities, as it results in excessively higher prices and poor quality services.
} 
and significantly related to the likelihood of privatization, supporting the hypothesis of the pressure against privatization exerted by local lobbies of public employees on local governments.

A positive and statistically significant relationship is found between the variable NEIGHBORING EFFECT and the privatization of water services. This finding is also in line with previous literature (Miralles, 2008) and could be explained by two main reasons (González-Gómez et al, 2011). On the one hand, firms already established in an area might wish to expand their business to take full advantage of economies of scale by offering attractive deals to neighboring municipalities; on the other hand, the experience of other municipalities in the vicinity can reduce the uncertainty in decision-making processes thus facilitating privatization. CONSORTIUM has a positive and significant relationship with the likelihood of privatization, supporting the idea of the interest of private water utilities in managing water services in larger areas in order to exploit economies of scale.

Finally, relationships without statistical significance are found for the variables FINANCIAL Burden, WATER CAPTURE SyStem, IDEOLOGY and MEDITERRANEAN RIVER BASIN. Concerning FINANCIAL BURDEN, our result is consistent with empirical findings on the privatization of public services in Europe (Bel and Fageda, 2007, 2009). In our view, the existence of unbalanced fiscal situations might push local governments to outsource municipal services in a search for extraordinary sources of income. However, private firms might also be reluctant to take over the provision of water services in municipalities with high fiscal deficits because water infrastructures are expected to be in poorer condition. The fact that variable IDEOLOGY is not significant might reflect a pragmatic approach on behalf of the largest parties to the choices on public service management. Indeed, this is a very frequent result in the empirical literature on public service privatization (Bel and Fageda, 2007, 2009). Lastly, lack of statistical significance of the geographical variable representing the river basin 
municipalities belong to is also in line with previous literature (González-Gómez et al, 2011).

\subsection{Results for the determinants of water prices}

Regarding the results obtained for the parameters in the price equation, the variable $P O P U$ LATION is found to exert a significant and positive effect on water prices in all models. On the contrary, the sign estimated for the variable DENSITY OF POPULATION is negative and statistically significant, suggesting the existence of economies of density in the provision of water services, which could result in lower prices. The estimated parameter for the variable STRONG WATER TREATMENT is statistically significant and has the expected sign. More intensive treatment to ensure the quality and drinkability of water for residential use entails higher costs and therefore higher prices. There is also a close relationship between the treatment used for making water suitable for human consumption and its source. Generally, surface water is poorer quality than water from underground, since it is more exposed to external pollutants and, therefore, needs more intensive treatment in order to make it suitable for human consumption.

The result obtained for the variable CONSORTIUM suggests that the association of municipalities is a good strategy to reduce costs, such that prices are significantly lower when a single manager provides the service to several surrounding municipalities. ${ }^{13}$ Moreover, the significant and negative relationship between PRIVATE MANAGEMENT and water prices indicates that prices are higher when the service is managed by an institutional public-private part-

\footnotetext{
${ }^{13}$ Alternatively, one could believe that having a consortium would lead a firm to enjoy greater market power, thus raising water prices. In practice, this implies that the variable CONSORTIUM would be positively correlated with the market share of the supplying firm; however, we have re-estimated our model 4 excluding the variable CONSORTIUM in the price equation and the sign and statistical significance of the coefficient for the variable MARKET SHARE OF THE SUPPLYING FIRM is maintained.
} 
nership (mixed firm). The more direct control that the local government exerts on managing the service in an institutional public-private partnership probably leads to more ambitious conditions regarding the extent and quality of water services, which will tend to result in higher costs and ultimately higher prices to be paid by the user.

Finally, results for firm dummies show the existence of different business strategies in the policy of water pricing in Andalusia. ${ }^{14}$ The sign and statistical significance obtained for the parameter of the variable DUMMY FOR FIRM4 suggests that this firm sets higher prices for water. Although the result is less robust, it also appears that the firm represented by DUMMY FOR FIRM2 sets higher water prices.

Turning to the results obtained for the variables representing market concentration, our results indicate that there is a significant and positive relationship between the degree of market concentration and water prices. Moreover, this result is robust and appears in all our models. In models 1 to 3, the estimated coefficients for variables $C R 1, C R 2$ and $H H I$ are all positive and statistically significant. This relationship may be due to the strategy followed by water firms at the time to bid for the tender to privatize the service. In areas with higher market concentration, bidding companies foresee the competition of a smaller number of competitors in public tenders and, consequently, propose a higher price for water. Similarly, the parameter of the variable MARKET SHARE OF THE SUPPLYING FIRM is positively and significantly related to the price of water, suggesting that the bargaining power of water firms in the annual process of reviewing prices is greater when its market share is higher. With incomplete contracts and asymmetric information, greater market power facilitates the exploitation of positioning advantages in the sector.

\footnotetext{
${ }^{14}$ In compliance with confidentiality commitments, in Table 4 the dummies for the five leading firms have been randomly renamed as DUMMY FOR FIRM1 to DUMMY FOR FIRM5.
} 
The result for the variables representing the time elapsed since the management of the service was privatized for the first time is also that expected. On the one hand, a positive relationship between the price of water and the variable YEARS SINCE PRIVATIZATION is obtained, showing that firms tend to raise their prices once they have been awarded the service. On the other hand, the negative sign of the variable YEARS SINCE PRIVATIZATION-SQUARED suggests that, as years go by, the increase in prices is smaller. Probably, given that contracts for the supply of water services have a limited duration, proximity to the time of completion encourages companies to moderate their rises in water prices and therefore safeguard their interests. First, because the local government can decide to re-municipalize the water service at the end of the contract and, secondly, because even if there is a new public tender to choose a private manager for the service, local governments could encourage proposals from new bidders.

In summary, the results of our research show that the degree of market concentration influences the price for water set by private firms in Andalusia. Existing market concentration in certain areas of Andalusia, in the context of a clearly oligopolistic industry, is reflected in higher prices for residential water. Furthermore, our findings regarding the positive relationship between market concentration and water prices within a framework of competition for the market are consistent with the existing literature on market concentration and prices within frameworks of competition in the market. As found in these last environments, the effect of concentration on prices in the water sector could be explained by the higher probability of collusion, given that market concentration makes it easier coordinating collusive prices, and detecting that another company is breaking the collusive agreement. Also, a dominant firm may follow a price-leadership strategy leading to higher prices.

Additionally, in order to test the robustness of our results against different definitions of the price variable, we have re-estimated all our models in two alternative scenarios in which 
prices are represented by a bill corresponding to consumption of 10 and $20 \mathrm{~m}^{3}$, respectively. The results are presented in Appendix 2. For the sake of simplicity, only the parameters estimated for the variables representing market concentration are reported. These parameters confirm that the relationship between water prices and market concentration is robust to the definition of the price variable. ${ }^{15}$

Finally, it is also worth highlighting that a highly suitable variable for measuring competition when franchising the water service could have been the number of firms participating in the competitive bidding processes. In this sense, the Auction Theory predicts that the more bidders when franchising the water service, the lower water prices should be, as a result of greater competition. Unfortunately, our sources of data have not allowed us to obtain this variable for all the auctions in which urban water services in Andalusian municipalities were privatized. ${ }^{16}$

\footnotetext{
${ }^{15}$ The statistical significance of the parameters for the remaining variables in the price equation and variables in the privatization equation makes no difference with respect to those reported in Table 4.

${ }^{16}$ The information about the number of bidders is managed by local governments at the time of resolving competitive bidding processes and is then incorporated into an administrative dossier and filed. In the course of elaborating our database, we submitted requests for this information to all the councils of Andalusian municipalities that had privatized urban water services, but after insisting on several occasions, we only received a positive response from slightly more than 40 municipalities. In addition, many of these cases corresponded to joint privatizations of water services in a consortium of municipalities, so the number of bidders was the same for all municipalities included in the consortium. These features considerably reduced the variability of the number of bidders, such that introducing it in our estimations makes it difficult to obtain statistically significant results. In any case, when we re-estimate our model using the number of bidders as an explanatory variable representing competition in the price equation, the parameter associated to this variable is not statistically significant and the performance of the model is perceptibly poorer when compared to the models in Table 4. The results of these estimations are available upon demand.
} 
The main policy implication of our results is that market concentration increases water prices. This would be the consequence of regulatory failures, such as the absence of effective regulation of the pricing processes for water in the region studied. The only control over the awarding of tenders and tariff review processes is exerted by local governments, but it might not be enough to compensate for competition failures in the industry. Furthermore, local government control is usually exerted by unskilled bureaucrats, who are at a disadvantage in relation to private service managers (Martínez-Espiñeira et al, 2009). Moreover, there is no independent body in Andalusia, such as those which are common in English-speaking countries, for instance Ofwat in the United Kingdom or the provincial regulatory authorities in Australia, which control the process of water pricing and/or perform comparative analyses of the activity of water utilities in order to highlight situations of inefficiency or abuse of dominant positions in the market.

The most similar organisms in Andalusia to those mentioned above are the Andalusian $\mathrm{Wa}$ ter Council and the Andalusian Water Observatory, both dependent from the regional government and, in our opinion, with very limited capacity to control the process of water pricing and monitoring the activity of the water industry in the region. The Andalusian Water Council was created in 1995 and plays the role of advisory body for regional policymakers. The Andalusian Water Observatory was approved in 2012 (Law 52/2012) also as an advisory organism, and is mainly intended to perform studies related to issues such as the urban demand for water, the costs of the management of the service and the structure of water tariffs. However, lack of independence introduces reasonable doubts about its actual capacity to monitor the activity of the Andalusian water industry. Lastly, and most importantly, despite having been approved in 2012, the Andalusian Water Observatory is not still operative due to not being endowed with budgetary resources. 


\section{Summary and conclusions}

In recent decades, some governments in developed countries have privatized the management of urban water services; however, the debate is still open and social reluctance to privatization is increasing (Hall and Lobina, 2012). In Italy a nationwide referendum held on 12-13 June 2011 rejected national legislation that intended to make water service privatization and liberalization compulsory. Furthermore, urban water delivery has been recently remunicipalized in important European cities such as Paris in 2010 and Berlin in 2013, and re-municipalization is also a widespread phenomenon in Hungary. Public dissatisfaction with water prices and lack of competition under private delivery are among the main drivers of pressures for re-municipalization.

In this framework, this research studies the relationship between the market structure in the private sector of the water industry and the price of water for residential uses. Our main contribution is to analyze whether market concentration affects water prices charged by private companies. In order to do so, information belonging to a sample of municipalities located in the Southern Spanish region of Andalusia is used. Empirical evidence is obtained of the relationship between market concentration and water prices. In the first place, it is found that higher market concentration at the time the service is awarded leads to higher water prices. Secondly, once the contract for the provision of the service is awarded, firms with a larger market share make their dominant position effective by setting higher prices for water. Thus, market concentration is associated with higher prices. The absence of specific regulation from an independent organism that supervises the process of tariff reviews further aggravates the situation. Therefore, it seems that potential competition failures in the water industry have not been well resolved by Andalusian legislators.

Finally, our results enable some recommendations to be made for economic policy. Firstly, privatization of the management of urban water services must be accompanied by mecha- 
nisms that promote more intense competition in the industry, both in relation to public tenders and also to the level of market concentration once the service is awarded. Secondly, it seems advisable to create independent bodies to control the behavior of water utilities and, in particular, their pricing policies and the way prices are reviewed. Benchmarking or comparing the productive activity of companies might also be a useful tool to regulate the process of establishing water prices.

\section{References}

Bakker, K, 2010, "Privatizing water: Governance failure and the world's water crisis" Ithaca, NY: Cornell University Press.

Bel G, Costas A, 2006, "Do public sector reforms get rusty? Local privatization in Spain" Journal of Policy Reform 9 (1) 1-24.

Bel G, Fageda X, 2007, "Why do local governments privatize public services? A survey of empirical studies" Local Government Studies 33 (4) 517-534.

Bel G, Fageda X, 2009, "Factors explaining local privatization: a meta-regression analysis" Public Choice 139 (1) 105-119.

Bel G, Fageda X, 2010, "Partial privatization in local services delivery: An empirical analysis on the choice of mixed firms" Local Government Studies 36 (1) 129-149.

Bel G, Fageda X, Warner M E, 2010, "Is private production of public services cheaper than public production? A meta-regression analysis of solid waste and water services" Journal of Policy Analysis and Management 29 (3) 553-577. 
Bel, G, González-Gómez F, Picazo-Tadeo A J, 2013, “The dynamics of privatization and regulation of water services: A comparative study of two Spanish regions" International Journal of Water Resources Development 29 (3) 373-384.

Bel G, Warner M E, 2008, "Challenging issues in local privatization" Environment and Planning C: Government and Policy 26 (1) 104-109

Belleflamme P, Peitz M, 2010, "Industrial organization. Markets and strategies" Cambridge, UK: Cambridge University Press.

Bottasso A, Conti M, 2009, "Scale economies, technology and technical change in the water industry: Evidence from the English water only sector" Regional Science and Urban Economics 39 (2) 138-147.

Brown T, Potoski M, 2005, “Transaction costs and contracting: The practitioner perspective" Public Performance and Management Review 28 (3) 326-351.

Carpentier A, Nauges C, Reynaud A, Thomas A, 2006, "Effets de la délégation sur le prix de l'eau potable en France: Une analyse à partir de la littérature sur les effets de traitement" Economie et Prévision 174 (3) 1-20.

Castillo-Manzano J I, Lopez-Valpuesta L, Marchena-Gómez, M, Pedregal D, 2013, “How much does water consumption drop when each household takes charge of its own consumption? The case of the city of Seville" Applied Economics 45 (32) 4465-4473.

Chong E, Huet F, Saussier S, Steiner F, 2006a, "Public-private partnerships and prices: Evidence from water distribution in France" Review of Industrial Organization $29(1 / 2)$ 149-169. 
Chong E, Huet F, Saussier S, 2006b, “Auctions, ex post competition and prices: the efficiency of public-private partnerships" Annals of Public and Cooperative Economics 77 (4), $521-554$.

Cruz N, Marques R, 2012, "Mixed companies and local governance: No man can serve two masters" Public Administration 90 (3) 737-758.

Dijkgraaf E and Gradus R H J M, 2008, "Institutional developments in the Dutch wastecollection market" Environment and Planning C: Government and Policy 26 (1) 110-126.

EC, European Commission, 2004. "Guidelines on the assessment of horizontal mergers under the Council Regulation on the control on concentrations between undertakings" Official Journal C 31 (05.02.2004), 5-18.

Furlong K, Bakker K, 2010, "The contradictions in 'alternative' service delivery: governance, business models, and sustainability in municipal water supply" Environment and Planning C: Government and Policy 28 (2) 349 - 368

Garcia S, Guérin-Schneider L, Fauquert G, 2005, “Analysis of water price determinants in France: cost recovery, competition for the market and operator's strategy" Water Science and Technology: Water Supply 5 (6) 173-181.

García-Valiñas M A, Martínez-Espiñeira R, González-Gómez F, 2010, "Measuring water affordability: A proposal for urban centres in developed countries" International Journal of Water Resources Development 26 (3) 441-458.

García-Valiñas M A, González-Gómez F, Picazo-Tadeo A J, 2012, "Is the price of water for residential use related to provider ownership? Empirical evidence from Spain" Utilities Policy 24 (1) 59-69. 
González-Gómez F, García-Rubio M A, 2008, "Efficiency in the management of urban water services. What have we learned after four decades of research?" Hacienda Pública Española. Revista de Economía Pública 185 (2) 39-67.

González-Gómez F, Guardiola J, 2009, “A duration model for the estimation of the contracting-out of urban water management in Southern Spain" Urban Affairs Review 44 (6) $886-906$.

González-Gómez F, Guardiola, J, Ruiz-Villaverde, A, 2009. Reconsidering privatization in the governance of water in Spain. Municipal Engineer 162 (3) 159-164.

González-Gómez F, Picazo-Tadeo A J, Guardiola Wanden-Berghe J, 2011, "Why do local governments privatize the provision of water services? Empirical evidence from Spain" Public Administration 89 (2) 471-492.

González-Gómez F, García-Rubio M A, Guardiola J, 2012, “Urban water service policies and management in Spain: Pending issues" International Journal of Water Resources Development 28 (1) 89-106.

Hall D, Lobina E, 2012, "Water companies and trends in Europe” Brussels, European Federation of Public Service Unions.

Heckman J, 1976, “The common structure of statistical models of truncation, sample selection and limited dependent variables and a simple estimator for such models" Annals of Economic and Social Measurement 5 475-492.

Heckman J, 1979, "Sample selection bias as a specification error" Econometrica 47 (1) $153-162$.

Kim H Y, Clark R M, 1988, “Economies of scale and scope in water supply” Regional Science and Urban Economics 18 (4) 479-502. 
Kuenne R E, 1989, "Uncertainty, spatial proximity, and the stability of oligopoly pricing" Environment and Planning A 21 (8) 1001-1013.

Instituto Nacional de Estadística (INE), 2011, “Encuesta sobre el suministro y saneamiento del agua. Año 2009” Madrid. Spain.

Martinez-Espiñeira R, García-Valiñas M A, González-Gómez F, 2009, “Does private management of water supply services really increase prices? An empirical analysis" Urban Studies 46 (4) 923-945.

Miralles A, 2008, "The link between service privatization and price distribution among consumer types: municipal water services in the Spanish region of Catalonia" Environment and Planning C: Government and Policy 26 (1) 159-172.

Olmos-Giupponi B, 2013, "Water governance in Spain. A dynamic system in transition”. In Gunawansa A and Bhullar L (eds.). Water governance. An evaluation of alternative architectures. Edward Elgar Publishing Ltd.: Cheltenham. p. 139-163.

Pérard E, 2009, "Water supply: Public or private? An approach based on cost of funds, transaction costs, efficiency and political costs" Policy and Society 27 (3) 193-219.

Picazo-Tadeo A J, González-Gómez F, Guardiola J, Ruiz-Villaverde A, 2012, “Do ideological and political motives really matter in the public choice of local services management? Evidence from urban water services in Spain" Public Choice 151 215-228.

Ruester S, Zschille M, 2010, “The impact of governance structure on firm performance: An application to the German water distribution sector" Utilities Policy 18 (3) 154-162.

Ruiz-Villaverde A, García-Rubio M A, González-Gómez F, 2010, “An analysis of urban water management in historical perspective: Evidence for the Spanish case" International Journal of Water Resources Development 26 (4) 653-674. 
Thorsten R E, Eskaf S, Hughes J, 2009, “Cost plus: Estimating real determinants of water and sewer bills" Public Works Management and Policy 13 (3) 224-238.

USDJ\&FTC, 2010, "Horizontal merger guidelines" Washington DC, US Department of Justice and the Federal Trade Commission.

Warner M, Bel G, 2008 “Competition or monopoly? Comparing privatization of local public services in the US and Spain" Public Administration 86 (3), 723-735.

Wooldridge J M, 2002, “Econometric analysis of cross section and panel data” Cambridge, MA: MIT Press. 
Table 1. Market shares of private contracts for water supply in Andalusia and concentration indices. Year 2009

\begin{tabular}{lrr}
\hline & Municipalities & Population \\
\hline Share of the market (\%) & & \\
Aqualia & 30.3 & 41.8 \\
Aquagest & 26.6 & 36.7 \\
Acciona & 23.8 & 9.0 \\
Agua y Gestión & 7.3 & 5.5 \\
Gestagua & 6.7 & 5.4 \\
Hidrogestión & 2.2 & 0.8 \\
Urbaser & 1.6 & 0.4 \\
Añil & 1.1 & 0.1 \\
Concentration indices & & \\
CR1 (\%) & 30.3 & 41.8 \\
CR2 (\%) & 56.9 & 78.5 \\
HHI & 0.23 & 0.32 \\
\hline
\end{tabular}

Source: own elaboration with data from Andalusian municipalities and utilities.

Table 2. Sample description: water prices of private water utilities

\begin{tabular}{lrrrr}
\hline Variable & Mean & $\begin{array}{r}\text { Standard } \\
\text { deviation }\end{array}$ & Maximum & Minimum \\
\hline Fixed quota (€ per month) & 2.18 & 0.72 & 5.38 & 0.65 \\
Price per m ${ }^{3}$ for a consumption of $(€)$ : & & & & \\
$5 \mathrm{~m}^{3}$ & 0.34 & 0.12 & 0.76 & 0.05 \\
$10 \mathrm{~m}^{3}$ & 0.41 & 0.14 & 0.78 & 0.05 \\
$15 \mathrm{~m}^{3}$ & 0.52 & 0.18 & 0.86 & 0.11 \\
$20 \mathrm{~m}^{3}$ & 0.64 & 0.24 & 1.20 & 0.15 \\
$25 \mathrm{~m}^{3}$ & 0.75 & 0.29 & 1.53 & 0.18 \\
$50 \mathrm{~m}^{3}$ & 1.07 & 0.45 & 2.24 & 0.41 \\
Price of a bill with a consumption of $(€$, including & & & & \\
fixed quota and water consumed): & & & & \\
$10 \mathrm{~m}^{3}$ & 6.31 & 1.77 & 11.24 & 1.88 \\
$15 \mathrm{~m}^{3}$ & 9.96 & 2.94 & 16.12 & 2.90 \\
$20 \mathrm{~m}^{3}$ & 15.01 & 5.12 & 26.71 & 4.40 \\
\hline
\end{tabular}

Source: own elaboration with data from the Official Gazettes of Andalusian provinces. 
Table 3. Sample description: explanatory variables ${ }^{\text {a }}$

\begin{tabular}{|c|c|c|c|c|}
\hline Variable & Mean & $\begin{array}{l}\text { Standard } \\
\text { deviation }\end{array}$ & Maximum & Minimum \\
\hline \multicolumn{5}{|l|}{ VARIABLES IN THE PRICE EQUATION (162 observations) } \\
\hline Population (thousands) & 18.7 & 32.1 & 234.3 & 0.3 \\
\hline Density of population (thousands inhabitants per $\mathrm{km}^{2}$ ) & 0.424 & 0.920 & 6.940 & 0.005 \\
\hline Strong water treatment (dummy) & 0.648 & - & - & - \\
\hline Consortium (dummy) & 0.556 & - & - & - \\
\hline Private management (dummy) & 0.475 & - & - & - \\
\hline Dummy for Aqualia & 0.278 & - & - & - \\
\hline Dummy for Aquagest & 0.333 & - & - & - \\
\hline Dummy for Acciona & 0.222 & - & - & - \\
\hline Dummy for Agua y Gestión & 0.074 & - & - & - \\
\hline Dummy for Gestagua & 0.062 & - & - & - \\
\hline \multicolumn{5}{|l|}{ Variables representing market concentration } \\
\hline Market concentration $(C R 1)$ & 0.602 & 0.165 & 1 & 0.253 \\
\hline Market concentration $(C R 2)$ & 0.811 & 0.103 & 1 & 0.491 \\
\hline Market concentration $(H H I)$ & 0.428 & 0.183 & 1 & 0.190 \\
\hline Market share of the supplying firm & 0.425 & 0.264 & 1 & 0.001 \\
\hline Years since privatization & 10.3 & 5.6 & 24 & 1 \\
\hline \multicolumn{5}{|c|}{ VARIABLES IN THE PRIVATIZATION EQUATION (715 observations) } \\
\hline Population (thousands) & 7.5 & 25.0 & 503.3 & 0.1 \\
\hline Financial burden & 3.701 & 2.801 & 25.59 & 0.001 \\
\hline Income per capita (€ per inhabitant) & 2,298 & 921 & 8,100 & 369 \\
\hline Public employment (percentage) & 9.2 & 5.5 & 42.6 & 0.0 \\
\hline Neighboring effect (percentage) & 21.4 & 13.7 & 52.2 & 0.0 \\
\hline Consortium (dummy) & 0.343 & - & - & - \\
\hline Water capture system (dummy) & 0.706 & - & - & - \\
\hline Ideology (dummy) & 0.186 & - & - & - \\
\hline Mediterranean river basin (dummy) & 0.337 & - & - & - \\
\hline
\end{tabular}

\footnotetext{
a For dummy variables only the means are provided, which represent the percentage of positive outcomes.
} 
Table 4. Determinants of the price of water in private utilities

\begin{tabular}{|c|c|c|c|c|}
\hline Variable & Model 1 & Model 2 & Model 3 & Model 4 \\
\hline \multicolumn{5}{|l|}{ PRICE EQUATION } \\
\hline $\begin{array}{l}\text { Constant } \\
\text { Population } \\
\text { Density of population } \\
\text { Strong water treatment } \\
\text { Consortium } \\
\text { Private management } \\
\text { Dummy for firm } 1 \\
\text { Dummy for firm } 2 \\
\text { Dummy for firm } 3 \\
\text { Dummy for firm } 4 \\
\text { Dummy for firm } 5\end{array}$ & $\begin{array}{l}5.263^{* * *} \\
0.020^{* *} \\
-0.528^{* *} \\
1.209^{* * *} \\
-2.938^{* * *} \\
-2.755^{* * *} \\
0.238 \\
1.950^{*} \\
0.059 \\
3.532^{* * *} \\
0.767\end{array}$ & $\begin{array}{l}3.157 \\
0.018^{* *} \\
-0.524^{* *} \\
1.215^{* * *} \\
-2.997^{* * *} \\
-2.725^{* * *} \\
0.242 \\
1.970^{*} \\
0.069 \\
3.063^{* *} \\
0.850\end{array}$ & $\begin{array}{l}5.754^{* * *} \\
0.018^{* *} \\
-0.511^{* *} \\
1.068^{* *} \\
-2.726^{* * *} \\
-2.727^{* * *} \\
0.003 \\
1.825^{*} \\
-0.059 \\
3.095^{* *} \\
0.695\end{array}$ & $\begin{array}{l}6.092^{* * *} \\
0.021^{* *} \\
-0.535^{* *} \\
1.248^{* * *} \\
-2.267^{* * *} \\
-2.044^{* * *} \\
-0.673 \\
0.957 \\
0.437 \\
2.507^{* *} \\
1.313\end{array}$ \\
\hline $\begin{array}{l}\text { Variables representing market concer } \\
\text { Market concentration }(C R 1) \\
\text { Market concentration }(C R 2) \\
\text { Market concentration }(H H I) \\
\text { Market share of the supplying firm } \\
\text { Years since privatization } \\
\text { Years since privatization-squared }\end{array}$ & $\begin{array}{l}2.800^{* *} \\
- \\
- \\
- \\
0.338^{* *} \\
-0.015^{* *}\end{array}$ & $\begin{array}{l}- \\
-329^{* *} \\
- \\
- \\
0.428^{* *} \\
-0.019^{* *}\end{array}$ & $\begin{array}{l}- \\
- \\
3.056^{* * *} \\
- \\
0.385^{* *} \\
-0.017^{* *}\end{array}$ & $\begin{array}{l}- \\
- \\
- \\
2.535^{* *} \\
0.279^{*} \\
-0.012^{*}\end{array}$ \\
\hline \multicolumn{5}{|l|}{ PRIVATIZATION EQUATION } \\
\hline $\begin{array}{l}\text { Constant } \\
\text { Population } \\
\text { Population-squared } \\
\text { Financial burden } \\
\text { Income per capita } \\
\text { Public employment } \\
\text { Neighboring effect } \\
\text { Consortium } \\
\text { Water capture system } \\
\text { Ideology } \\
\text { Mediterranean river basin }\end{array}$ & $\begin{array}{l}-2.491^{* * * *} \\
0.034^{* * *} \\
-1.4 \mathrm{e}-7^{* * *} \\
-0.011 \\
4.2 \mathrm{e}-4^{* * *} \\
-0.050^{* * *} \\
0.030^{* * *} \\
0.639^{* * *} \\
0.164 \\
0.013 \\
0.196\end{array}$ & $\begin{array}{c}-2.493^{* * *} \\
0.035^{* * *} \\
-1.4 \mathrm{e}-7^{* * *} \\
-0.009 \\
4.2 \mathrm{e}-4^{* * *} \\
-0.049^{* * *} \\
0.030^{* * *} \\
0.637^{* * *} \\
0.161 \\
0.009 \\
0.195\end{array}$ & $\begin{array}{l}-2.453^{* * *} \\
0.034^{* * *} \\
-1.4 \mathrm{e}-7^{* * *} \\
-0.009 \\
4.2 \mathrm{e}-4^{* * *} \\
-0.052^{* * *} \\
0.030^{* * *} \\
0.635^{* * *} \\
0.168 \\
0.011 \\
0.181\end{array}$ & $\begin{array}{c}-2.486^{* * *} \\
0.034^{* * *} \\
-1.4 \mathrm{e}-7^{* * *} \\
-0.006 \\
4.1 \mathrm{e}-4^{* * *} \\
-0.048^{* * *} \\
0.031^{* * *} \\
0.621^{* * *} \\
0.160 \\
0.023 \\
0.160\end{array}$ \\
\hline $\begin{array}{l}\text { Rho } \\
\text { LR test of } r h o=0 \text { (Chi-squared) }\end{array}$ & $\begin{array}{l}0.765 \\
25.91^{* * *}\end{array}$ & $\begin{array}{c}0.759 \\
24.92^{* * *}\end{array}$ & $\begin{array}{l}0.741 \\
20.95^{* * *}\end{array}$ & $\begin{array}{l}0.761 \\
23.77^{* * *}\end{array}$ \\
\hline $\begin{array}{l}\text { Log likelihood } \\
\text { Wald Chi-squared }\end{array}$ & $\begin{array}{l}-647.2 \\
93.77^{* * *}\end{array}$ & $\begin{array}{l}-647.3 \\
93.49^{* * *}\end{array}$ & $\begin{array}{l}-645.5 \\
99.25^{* * *}\end{array}$ & $\begin{array}{l}-647.0 \\
92.60^{* * *}\end{array}$ \\
\hline $\begin{array}{l}\text { Number of observations } \\
\text { Observations in the price equation }\end{array}$ & \multicolumn{4}{|c|}{162} \\
\hline
\end{tabular}

${ }^{a}{ }^{*}$ Significant at $10 \% ;{ }^{* *}$ significant at $5 \% ;{ }^{* * *}$ significant at $1 \%$. 


\begin{tabular}{|c|c|c|}
\hline Variable & Description & Source \\
\hline \multicolumn{3}{|c|}{ VARIABLES IN THE PRICE EQUATION } \\
\hline Price & $\begin{array}{l}\text { Price for a bill with average consumption of } 15 \mathrm{~m}^{3} \text {, including } \\
\text { fixed quota }\end{array}$ & $\begin{array}{l}\text { Official Gazettes } \\
\text { of the Andalusia } \\
\text { provinces }\end{array}$ \\
\hline Population & Population in 2009 , in 1,000 s of inhabitants & \multirow{2}{*}{$\begin{array}{l}\text { Municipal Census. } \\
\text { National Institute } \\
\text { of Statistics }\end{array}$} \\
\hline $\begin{array}{l}\text { Density of } \\
\text { population }\end{array}$ & Number of inhabitants per kilometer-squared in 2009 & \\
\hline $\begin{array}{l}\text { Strong water } \\
\text { treatment }\end{array}$ & $\begin{array}{l}\text { Dummy variable that takes a value of } 1 \text { if water needs strong } \\
\text { treatment (type A } 2 \text { or A } 3 \text { chemical treatment) in order to make } \\
\text { it suitable for human consumption, and } 0 \text { otherwise }\end{array}$ & $\begin{array}{l}\text { Ministry of Health } \\
\text { and Social Policy }\end{array}$ \\
\hline Consortium & $\begin{array}{l}\text { Dummy variable that takes a value of } 1 \text { if in } 2009 \text { the } \\
\text { supplying firm belongs to a consortium that provides water } \\
\text { services to several neighboring municipalities, and } 0 \text { otherwise }\end{array}$ & \multirow{3}{*}{ Water utilities } \\
\hline $\begin{array}{l}\text { Private } \\
\text { management }\end{array}$ & $\begin{array}{l}\text { Dummy variable that takes a value of } 1 \text { for private firms } \\
\text { (contractual PPPs) and } 0 \text { for mixed firms (institutionalized } \\
\text { PPPs). The data refer to } 2009\end{array}$ & \\
\hline $\begin{array}{l}\text { Dummies for } \\
\text { Aqualia, Acciona, } \\
\text { Aquagest, Agua y } \\
\text { Gestión and } \\
\text { Gestagua }\end{array}$ & $\begin{array}{l}\text { Dummies that take a value of } 1 \text { if the observation belongs to } \\
\text { one of these five water utilities, and } 0 \text { otherwise }\end{array}$ & \\
\hline \multicolumn{3}{|c|}{ Explanatory variables representing market concentration } \\
\hline $\begin{array}{l}\text { Market } \\
\text { concentration } \\
(C R l)\end{array}$ & $\begin{array}{l}\text { Percentage of market share held by the largest firm in the year } \\
\text { of privatization, calculated on the basis of the population } \\
\text { supplied in the provincial market }\end{array}$ & \multirow{4}{*}{ Own elaboration } \\
\hline $\begin{array}{l}\text { Market } \\
\text { concentration } \\
(C R 2)\end{array}$ & $\begin{array}{l}\text { Percentage of market share held by the two largest firms in the } \\
\text { year of privatization, calculated on the basis of the population } \\
\text { supplied in the provincial market }\end{array}$ & \\
\hline $\begin{array}{l}\text { Market } \\
\text { concentration } \\
(H H I)\end{array}$ & $\begin{array}{l}\text { Hirschman-Herfindahl Index defined as the sum of the squares } \\
\text { of the market shares of all supplying firms, calculated on the } \\
\text { basis of the population supplied in the provincial market in the } \\
\text { year of privatization }\end{array}$ & \\
\hline $\begin{array}{l}\text { Market share of } \\
\text { the supplying firm }\end{array}$ & $\begin{array}{l}\text { Market share held by the supplying firm in year } 2009 . \text { This } \\
\text { share is calculated on the basis of the population supplied in } \\
\text { the provincial market. }\end{array}$ & \\
\hline $\begin{array}{l}\text { Years since } \\
\text { privatization }\end{array}$ & Years elapsed from the year of privatization to 2009 & Town Councils \\
\hline
\end{tabular}




\begin{tabular}{|c|c|c|}
\hline Variable & Description & Source \\
\hline \multicolumn{3}{|c|}{ VARIABLES IN THE PRIVATIZATION EQUATION } \\
\hline Privatization & $\begin{array}{l}\text { Dummy variable that takes a value of } 1 \text { if the Council has } \\
\text { privatized the management of urban water services at the } \\
\text { end of the period 1986-2009 and } 0 \text { if the service has not } \\
\text { been privatized }\end{array}$ & $\begin{array}{l}\text { Town councils and } \\
\text { firms }\end{array}$ \\
\hline Population & $\begin{array}{l}\text { Population in } 1,000 \text { s of inhabitants. If the municipality } \\
\text { privatizes, it takes the value from the year prior to privat- } \\
\text { izing. In the case of not privatizing, it takes the average } \\
\text { value over the period } 1986-2009\end{array}$ & $\begin{array}{l}\text { National Institute of } \\
\text { Statistics }\end{array}$ \\
\hline Financial burden & $\begin{array}{l}\text { Sum of financial expenditures over sum of ordinary } \\
\text { revenues of the local government. In the case of } \\
\text { privatizing, this variable takes the value of the year before } \\
\text { the decision was taken. In the case of not privatizing, it } \\
\text { takes the mean over the period 1986-2009 }\end{array}$ & $\begin{array}{l}\text { Ministry of } \\
\text { Economic Affairs }\end{array}$ \\
\hline Income per capita & $\begin{array}{l}\text { Euros per inhabitant. If the municipality privatizes, it } \\
\text { takes the value from the year before privatizing. In the } \\
\text { case of not privatizing, it takes the average value over the } \\
\text { period } 1986-2009\end{array}$ & \multirow[t]{2}{*}{$\begin{array}{l}\text { Andalusia } \\
\text { Government }\end{array}$} \\
\hline $\begin{array}{l}\text { Public } \\
\text { employment }\end{array}$ & $\begin{array}{l}\text { Percentage of public employment over total employment } \\
\text { in the municipality. The data refer to year } 2001\end{array}$ & \\
\hline Neighboring effect & $\begin{array}{l}\text { Percentage of municipalities that have privatized within } \\
\text { the province the municipality belongs to. In the case of } \\
\text { privatization, it takes the value from the year before the } \\
\text { decision was made. In the case of no privatization, it } \\
\text { takes the average value over the period }\end{array}$ & $\begin{array}{l}\text { City and town } \\
\text { councils and private } \\
\text { firms }\end{array}$ \\
\hline Consortium & $\begin{array}{l}\text { In the case of privatizing, this dummy variable takes a } \\
\text { value of } 1 \text { if the council belonged to a consortium the } \\
\text { previous year and } 0 \text { otherwise. In the case of not } \\
\text { privatizing, it takes a value of } 1 \text { if the municipality } \\
\text { belongs to a consortium in the middle of the period 1986- } \\
2009 \text { and } 0 \text { if not }\end{array}$ & \multirow[t]{2}{*}{$\begin{array}{l}\text { Ministry of Regional } \\
\text { Policy }\end{array}$} \\
\hline $\begin{array}{l}\text { Water capture } \\
\text { system }\end{array}$ & $\begin{array}{l}\text { Dummy variable taking a value of } 1 \text { if water is captured } \\
\text { using mechanical means and } 0 \text { if it is captured using the } \\
\text { force of gravity }\end{array}$ & \\
\hline
\end{tabular}

\begin{tabular}{lll}
\hline & $\begin{array}{l}\text { Dummy variable that equals } 1 \text { if PP (right-wing party) } \\
\text { was in power in the local government when the decision } \\
\text { of privatizing was taken, and if the municipality did not } \\
\text { privatize and PP was in power at the end of the period. } \\
\text { Conversely, it takes a value of 0 if PSOE, IU or PA (left- } \\
\text { wing parties) were in power when the decision of privat- } \\
\text { izing was taken, and if the municipality did not privatize } \\
\text { and PSOE, IU or PA were in power at the end of the pe- } \\
\text { riod 1986-2009 }\end{array}$ & $\begin{array}{l}\text { Home Office and } \\
\text { Policy of Regional }\end{array}$ \\
\hline $\begin{array}{l}\text { Mediterranean } \\
\text { river basin }\end{array}$ & $\begin{array}{l}\text { Dummy variable taking a value of 1 if the municipality } \\
\text { belongs to the Mediterranean river basin and 0 otherwise }\end{array}$ & $\begin{array}{l}\text { Annual Report of } \\
\text { the Southern } \\
\text { Hydrographic } \\
\text { Federation }\end{array}$ \\
\hline
\end{tabular}


Appendix 2. Determinants of the price of water in private utilities considering different alternatives to measure prices

\begin{tabular}{|c|c|c|c|c|c|c|c|c|}
\hline \multirow[b]{2}{*}{ Explanatory variable } & \multicolumn{4}{|c|}{ Price of a bill with consumption of $10 \mathrm{~m}^{3}$} & \multicolumn{4}{|c|}{ Price of a bill with consumption of $20 \mathrm{~m}^{3}$} \\
\hline & Model 1 & Model 2 & Model 3 & Model 4 & Model 1 & Model 2 & Model 3 & Model 4 \\
\hline \multicolumn{9}{|l|}{ PRICE EQUATION } \\
\hline \multicolumn{9}{|c|}{ Variables representing market concentration } \\
\hline Market concentration (CRI) & $1.493^{*}$ & - & - & - & $4.365^{* *}$ & - & - & - \\
\hline Market concentration ( $C R 2)$ & - & $2.714^{* *}$ & - & - & - & 5.662 & - & - \\
\hline Market concentration $(H H I)$ & - & - & $1.535^{* *}$ & - & - & - & $4.555^{* *}$ & - \\
\hline Market share of the supplying firm & - & - & - & 0.357 & - & - & - & $4.652^{* *}$ \\
\hline Years since privatization & $0.201^{* *}$ & $0.266^{* *}$ & $0.221^{* *}$ & 0.163 & $0.570^{* *}$ & $0.667^{* *}$ & $0.638^{* *}$ & $0.500^{*}$ \\
\hline Years since privatization-squared & $-0.009^{* *}$ & $-0.011^{* *}$ & $-0.009^{* *}$ & $-0.007^{*}$ & $-0.025^{* *}$ & $-0.029^{* *}$ & $-0.028^{* *}$ & $-0.022^{*}$ \\
\hline Rho & 0.789 & 0.785 & 0.758 & 0.790 & 0.788 & 0.782 & 0.772 & 0.804 \\
\hline LR test of $r h o=0$ (Chi-squared) & $23.39^{* * *}$ & $22.47^{* * *}$ & $18.55^{* * *}$ & $22.90^{* * *}$ & $26.52^{* *}$ & $25.43^{* * *}$ & $21.94^{* * *}$ & $24.74^{* * *}$ \\
\hline Log likelihood & -564.8 & -564.2 & -563.8 & -566.4 & -728.3 & -729.0 & -727.1 & -727.3 \\
\hline Wald Chi-squared & $84.76^{* * *}$ & $86.47^{* * *}$ & $87.34^{* * *}$ & $79.09^{* * *}$ & $128.73^{* * *}$ & $126.05^{* * *}$ & $133.43^{* * *}$ & $131.78^{* * *}$ \\
\hline
\end{tabular}

${ }^{*}$ Significant at $10 \% ;{ }^{* *}$ significant at $5 \% ;{ }^{* * *}$ significant at $1 \%$. 